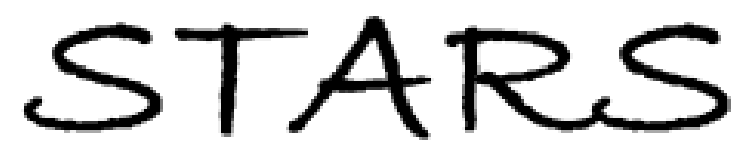

University of Central Florida

STARS

$1-1-2008$

\title{
Heat Stress in the Intertidal: Comparing Survival and Growth of an Invasive and Native Mussel Under a Variety of Thermal Conditions
}

Kimberly R. Schneider

University of Central Florida

Find similar works at: https://stars.library.ucf.edu/facultybib2000 University of Central Florida Libraries http://library.ucf.edu

This Article is brought to you for free and open access by the Faculty Bibliography at STARS. It has been accepted for inclusion in Faculty Bibliography 2000 s by an authorized administrator of STARS. For more information, please contact STARS@ucf.edu.

\section{Recommended Citation}

Schneider, Kimberly R., "Heat Stress in the Intertidal: Comparing Survival and Growth of an Invasive and Native Mussel Under a Variety of Thermal Conditions" (2008). Faculty Bibliography 2000s. 943.

https://stars.library.ucf.edu/facultybib2000/943

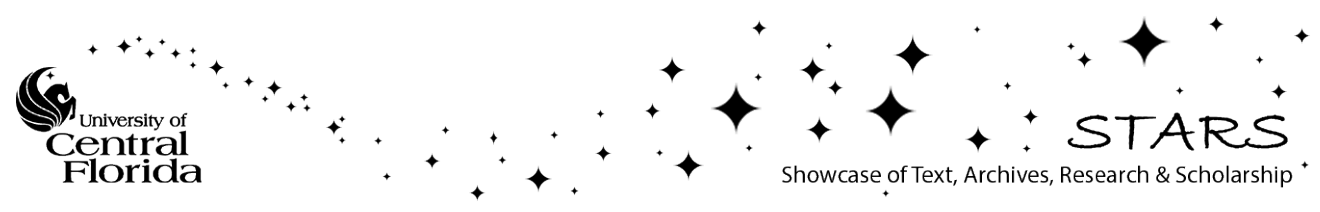




\title{
Heat Stress in the Intertidal: Comparing Survival and Growth of an Invasive and Native Mussel Under a Variety of Thermal Conditions
}

\author{
KIMBERLY R. SCHNEIDER* \\ University of South Carolina, Department of Biological Sciences, Columbia, South Carolina 29208
}

\begin{abstract}
In the rocky intertidal, organisms frequently experience a wide range of daily body temperatures depending on the stage of the tide and the time of day. In the intertidal, the thermal adaption of a species and its ability to invade a new region may be closely linked. In this research, the physiological effects of thermal stress in both low tide and high tide conditions are compared between Mytilus galloprovincialis, a worldwide mussel invader, and M. trossulus, a sibling species. In a seawater tank, mussels were exposed to one of three aerial temperature treatments $(20$, $25,30^{\circ} \mathrm{C}$ ) in a cycle with one of two water temperatures $\left(18,12{ }^{\circ} \mathrm{C}\right)$. In $18{ }^{\circ} \mathrm{C}$ water, there was no effect of the aerial treatments on growth or survival in either species. In contrast, in $12{ }^{\circ} \mathrm{C}$ water, aerial exposure affected the survival and growth of both species. Growth and survival rates of $M$. galloprovincialis were higher in all conditions than the rates of $M$. trossulus, especially in the $18{ }^{\circ} \mathrm{C}$ water experiments and in the aerial exposure treatments of the winter $12{ }^{\circ} \mathrm{C}$ water experiment. M. galloprovincialis appears to be warmadapted with regard to both low tide and high tide thermal stress. These results when paired with previous research suggest that as climates shift due to global warming, the temperatures favorable to $M$. galloprovincialis will become more common.
\end{abstract}

\section{Introduction}

Non-native species can cause a devastating ecological impact on invaded communities (Hoffman et al., 1999; Sax et al., 2005). For instance, endangered species frequently risk extinction due to competition or predation from intro-

Received 24 April 2008; accepted 24 August 2008.

* To whom correspondence should be addressed, at University of Central Florida, Biology Department, Orlando, FL 32316. E-mail: schneid@ mail.ucf.edu duced species (Wilcove et al., 1998). As barriers to organism dispersal continue to break down as a result of anthropogenic activities (e.g., release of ballast water), the threat of invasion continues to rise in both terrestrial and marine communities (Carlton and Geller, 1993; Cohen and Carlton, 1998; Mack et al., 2000; Wonham et al., 2001). Therefore, quantifying the attributes of organisms and ecosystems that facilitate or interfere with successful invasion is crucial to forecasting future invasions (e.g., Mack et al., 2000; Sax et al., 2005; Miller et al., 2007). However, such quantification remains a challenge because of the many factors that may influence invasion success (Mack et al., 2000).

Some progress has been made in identifying the general characteristics of successful invaders, such as their lifehistory strategies (e.g., reproductive potential, body size), adaptations to certain habitats, and release from predators and diseases in invaded communities (Rejmanek, 1996; Calvo-Ugarteburu and McQuaid, 1998; Radford and Cousens, 2000; Blackburn and Duncan, 2001). Other mechanisms that also may contribute significantly to the successful invasion of a species include its thermal adaptation (e.g., Stachowicz et al., 2002), which is the focus of the present research. The rocky intertidal is an ecosystem where thermal adaptation and invasability may be intimately intertwined, considering that marine intertidal organisms frequently contend with a wide range of daily body temperatures due to alternating exposure to the aquatic and aerial environments (i.e., high and low tides, respectively). For instance, during low tide the body temperature of a mussel can be $20{ }^{\circ} \mathrm{C}$ warmer than during high tide when body temperature tracks water temperature (Helmuth, 2002). Furthermore, recent studies that have compared the thermal tolerance of native and invasive marine species suggest that successful invaders have higher fitness in warmer climates compared to native species that occupy 
similar niches (e.g., Stachowicz et al., 2002; Nehls et al., 2006; Agius, 2007; Saunders and Metaxas, 2007; Schneider and Helmuth, 2007). An organism's physiological tolerance to thermal stress likely plays a significant role in its invasion potential.

The Mytilus edulis complex (blue mussels: M. edulis, $M$. trossulus, and $M$. galloprovincialis) represents an excellent system in which to study the role of thermal stress in intertidal species invasion. These species occur in subtidal and intertidal coastal habitats. Additionally, M. galloprovincialis is considered one of the 100 most successful invasive species in the world (Lowe et al., 2000). Over the past century, this species has established populations in the United States, South Africa, Japan, and Hong Kong (Wilkens et al., 1983; Lee and Morton, 1985; Hockey and Schurink, 1992; Geller, 1999; Wonham, 2004). The United States and Japanese invasions have occurred in areas where M. trossulus occurs naturally; thus, M. galloprovincialis has competed with and often replaced a sibling species (Wilkens et al., 1983; Geller, 1999). In the United States, M. galloprovincialis is suggested to have been introduced into southern California, where M. trossulus was endemic, in the early 1900s (Geller, 1999). The two mussels are morphologically similar species that hybridize when they co-occur (Seed, 1992). However, since the invasion, pure populations of M. galloprovincialis have expanded northward. Currently, mussels in southern California are almost exclusively M. galloprovincialis; mussels in northern California and Oregon are predominately M. trossulus; and both species as well as their hybrids occur in central California (Rawson et al., 1999).

To date, most studies of the population distribution in Mytilus spp. have focused on the limiting effects of water temperature on dispersal (e.g., Suchanek et al., 1997). In central California, Sagarin et al. (1999) and Barry et al. (1995) correlated intertidal faunal shifts between the early 1930s and the early 1990s with increased water temperatures. Those authors did not look at Mytilus spp., but a range expansion of M. galloprovincialis is thought to have occurred during the same time (see Geller, 1999). Observational studies suggest that $M$. trossulus prefers cooler water and M. galloprovincialis prefers warmer water (Sarver and Foltz, 1993; Suchanek et al., 1997). This difference in thermal preference has been further supported by research examining the degree of protein damage these species suffered under different regimes of water temperature (Hofmann and Somero, 1996a; Braby and Somero, 2006a). Thus, superior adaptation to warmer water may be one reason why $M$. galloprovincialis has been a successful invader.

Moreover, recent evidence suggests that exposure to aerial temperatures also affects the fitness of intertidal organisms (Hofmann and Somero, 1996b; Przeslawski, 2005; Schneider and Helmuth, 2007). For example, immunity, reproduction, and the acid-base balance of an intertidal organism can be affected by low tide temperature (e.g., Petes et al., 2007; Allen and Burnett, 2008). Hofmann and Somero (1996b) provide evidence that M. trossulus is thermally sensitive to aerial temperatures. A key finding of this study is that exposure to damaging temperatures occurs exclusively during aerial exposure at low tide. For intertidal organisms, temperature patterns in air can differ substantially from patterns in water (Helmuth et al., 2006). For example, along the west coast of the United States, although water temperatures generally decrease as one moves from south to north, maximum aerial mussel (M. californianus) body temperatures exhibit a mosaic pattern of alternating "hot" and "cold" spots (Helmuth et al., 2002, 2006). Patterns of heat-shock expression in M. californianus also appear to display a complex mosaic along this latitudinal gradient (Sagarin and Somero, 2006; Place et al., 2008). The relative physiological effects of emersed (i.e., aerial exposure) and immersed (i.e., water) thermal stress on mussels within the $M$. edulis complex remains relatively unexplored.

In the present study, I investigated the physiological effects of thermal stress on $M$. galloprovincialis (the invader) and $M$. trossulus (the native congener). To this end I examined the effects of both aerial exposure and water temperature on the growth and survival of both species under laboratory conditions. I hypothesized that M. galloprovincialis would show higher levels of growth and survival in both warmer water and aerial environments than would M. trossulus (Hofmann and Somero, 1996a; Braby and Somero, 2006a) and that aerial exposure to thermal stress would be an important factor in the growth and survival of the two species.

\section{Materials and Methods}

\section{Temperature regime}

In order to simulate the natural range of tidal thermal stress, mussel populations of Mytilus galloprovincialis and $M$. trossulus were established in seawater tanks that mimicked a daily tidal cycle by filling and draining at different times. During high tide, mussels were completely immersed in water. However, during simulated low tide, the mussels were exposed to one of three aerial temperature treatments. These treatments included body temperatures of $20{ }^{\circ} \mathrm{C}$ (cool), $25{ }^{\circ} \mathrm{C}$ (warm), and $30^{\circ} \mathrm{C}$ (hot). A subtidal control group also was established that remained underwater during the entire tidal cycle. Separate experiments were conducted in two different water temperatures: $18{ }^{\circ} \mathrm{C}$ and $12{ }^{\circ} \mathrm{C}$. Although in nature a variety of air and water temperatures occur within the distribution of $M$. galloprovincialis and $M$. trossulus, the above temperature regimes in this research represented those that (1) exist where the species co-occur in California (Braby and Somero, 2006b) and (2) are found 
during the summer along the west coast of the United States (see Helmuth et al., 2006; Braby and Somero, 2006b; Schneider and Helmuth, 2007).

Each experimental combination of each temperature combination was run for 9 weeks. Each water temperature was run twice. The experiments using the $18{ }^{\circ} \mathrm{C}$ water temperature were conducted from 24 June to 24 August in 2004 and from 4 July to 5 September in 2005. Experiments using the $12{ }^{\circ} \mathrm{C}$ water temperature ran from 1 February through 1 April and from 4 July to 5 September in 2005.

\section{Experimental tanks}

Experiments were run in an indoor seawater hall at the University of South Carolina, Columbia, South Carolina. A re-circulating tank $(2.1 \mathrm{~m} \times 0.65 \mathrm{~m} \times 0.6 \mathrm{~m})$ was used with a chiller attached to the system to maintain a constant water temperature of either $12{ }^{\circ} \mathrm{C}$ or $18{ }^{\circ} \mathrm{C}$. During the summer of 2005, two separate tanks were used for the $18{ }^{\circ} \mathrm{C}$ and $12{ }^{\circ} \mathrm{C}$ trials that were run simultaneously. A pump circulated the water continuously $24 \mathrm{~h}$ a day within the tank. To simulate a single daily low tide, a second pump released water from the system for $6 \mathrm{~h}$ a day. Two separated halogen lamps (Regent-WQ; no emission of ultraviolet light) were located over the tanks to regulate the body temperatures in the hot $\left(\approx 30{ }^{\circ} \mathrm{C} ; 500 \mathrm{~W}\right)$ and warm $\left(\approx 25{ }^{\circ} \mathrm{C}, 300 \mathrm{~W}\right)$ aerial exposure treatments. The lamps were on timers to coincide with the low tide cycle. Additionally, dividers were placed between the four treatments within each tank to ensure that the halogen lamps affected only the hot and warm aerial exposure treatments and not the cool and subtidal treatments. Practical salinity was maintained at 28 .

In each of the thermal treatment conditions, the mussels were placed on four tiles $(14 \mathrm{~cm} \times 14 \mathrm{~cm})$ located under the surface of the water during the simulated high tide. In the immersed treatment (i.e., subtidal control), the mussels were placed on tiles closer to the bottom so that they remained submerged during the simulated low tide; subtidal mussels were $25 \mathrm{~cm}$ above the bottom of the tank. Individuals of $M$. trossulus and M. galloprovincialis were labeled, mixed together, and assigned to one of the four tiles within each treatment. Individual mussels were not disturbed during the experiment unless clumps formed due to mussel movement (i.e.. mussel(s) attached on top of another mussel potentially shading bottom layer; see Schneider et al., 2005). When clumping did occur, mussels on the top were carefully removed and placed in an open space on their tile. Tiles were rotated biweekly to ensure that all mussels experienced similar overall thermal regimes. Furthermore, the locations of the four treatments within the tank were randomly changed on a weekly basis. Partial water changes were also carried out weekly.

\section{Organismal maintenance}

All mussels were obtained from Penn Cove Shellfish in Coupeville, Washington. This aquaculture facility raises $M$. trossulus and M. galloprovincialis under similar conditions. Both species were originally collected from Washington State populations; $M$. galloprovincialis is invasive in this area and the source population is unclear (pers. comm., I. Jefferds, Penn Cove Shellfish) but has likely been introduced multiple times (see Wonham, 2004). Mussels remain underwater in Puget Sound, Washington, after the larvae settle on submerged ropes in the aquaculture facility. Therefore, their thermal history includes no aerial exposure. The mussels were shipped overnight to Columbia, South Carolina. About 10 mussels of each species were genetically identified with a diagnostic genetic marker, Glu-5', after each shipment to confirm correct species assignment (KRS, unpubl. data). DNA was extracted with phenol chloroform and amplified by polymerase chain reaction (PCR) according to Rawson et al. (1996).

Upon arrival, mussels were put into seawater that had a temperature that corresponded with the water temperature at the aquaculture facility when they were collected. Mussels were collected in January and June when the water temperatures were $\approx 8-10{ }^{\circ} \mathrm{C}$ and $\approx 11-12{ }^{\circ} \mathrm{C}$, respectively. If the required experimental water temperature was higher than the temperature at the aquaculture facility, it was increased slowly, $1{ }^{\circ} \mathrm{C}$ every 1.5 days. The maximum increase was 6 ${ }^{\circ} \mathrm{C}$. All mussels were held in the tank for 10 days before being exposed for an additional week to periodic air exposure at room temperature $\left(\approx 20{ }^{\circ} \mathrm{C} ; 1 \mathrm{~h}\right.$ per day to a maximum of $6 \mathrm{~h}$ ). During the first week of each experiment, the mussels in the hot $\left(30^{\circ} \mathrm{C}\right)$ and warm $\left(25^{\circ} \mathrm{C}\right)$ aerial treatments were slowly exposed to the additional thermal exposure during low tide. Lamps were turned on for $0.5 \mathrm{~h}$ the first day, followed by an additional hour each day to a maximum of $6 \mathrm{~h}$ per day, which was maintained for the subsequent 8 weeks.

Mussels were fed daily an algal paste (Chaetoceros- $B$, Phaeodactylum tricornutum, Nannochloropsis oculata), obtained from Innovative Aquaculture (SPAT formula), upon arrival and throughout the experiment. The algal paste was mixed with seawater to form a $10 \%$ paste solution that was frozen in ice cube trays for easy and equal feedings. The number of ice cubes provided in a feeding depended on the number of live mussels at the time (about one ice cube to each 50 mussels). Mussels were fed $1 \mathrm{~h}$ after the tidal cycle to ensure equal initial feeding between all treatments.

All mussels used in the experiment were $20-30 \mathrm{~mm}$ in length. Prior to the start of the experiment, individuals were weighed (wet weight, after external drying; Ohaus Explorer, accuracy $0.00 \mathrm{~g}$ ) and measured for length. Small tags containing identification numbers were glued to the mussels' shells. At the end of each experiment, all surviving mussels 
were measured for length and weight to calculate their growth. Mussel mortality was checked daily at feeding time. A mussel was considered dead if it was floating or if its valve was open and it also did not respond to physical stimulation. In the first experiment (i.e., $18{ }^{\circ} \mathrm{C}$ water temperature, 2004), 30 mussels of each species were used in each treatment. In the other three experiments $\left(18{ }^{\circ} \mathrm{C}, 2005\right.$; $12{ }^{\circ} \mathrm{C}$ winter 2005 and summer 2005), 50-70 mussels were used per species per treatment.

\section{Temperature monitoring}

Mussel body temperatures were monitored throughout the experiments by biomimetic temperature loggers that thermally mimic the body temperatures of living mussels (Helmuth et al., 2002; Fitzhenry et al., 2004). To monitor temperature, additional mussel shells were emptied and filled with silicone; then iButton temperature loggers were placed in the centers of the shells (iButton data loggers, $1-\mathrm{cm}$ diameter, sample interval of $5 \mathrm{~min}$, accuracy of 0.5 $\left.{ }^{\circ} \mathrm{C}\right)$. One biomimetic temperature logger was deployed in the middle of each treatment (i.e., four loggers per tank) and exchanged weekly. The use of loggers was especially important because the body temperature of an intertidal organism during low tide can be very different than the air and water temperature (Helmuth, 1998, 2002). Thus, monitoring air temperature alone would not have provided an accurate estimate of the body temperature mussels experienced during the simulated low tide. During immersion, however, body temperature tracks water temperature.

\section{Statistical analyses}

A four-factor nested mixed-effect model analysis of variance (ANOVA) was run to look at the effects of aerial exposure, water temperature, season of trial, and species on growth (separate analyses for each growth variable-i.e., change in length and weight; Table 1). Several significant interactions were found between water temperature, aerial exposure, and species (Table 1). Thus, to compare the effects of aerial exposure on the growth, a two-way ANOVA were performed looking at species and aerial exposure for each trial. All statistics were performed separately for each of the four individual experiments (i.e., $18{ }^{\circ} \mathrm{C} 2004,18{ }^{\circ} \mathrm{C} 2005$, summer and winter 2005 at $\left.12{ }^{\circ} \mathrm{C}\right)$. To further elucidate the aerial treatment effects, pairwise comparisons between treatments within species were made using a Student's $t$-test; sequential Bonferroni corrections were conducted to correct for multiple comparisons (Rice, 1989). For all growth analyses data, only surviving mussels were included. ANOVAs were done in SAS 9.1 and JMP 5.1.

To examine the effects of aerial exposure on survivorship (i.e., days until death), a Kaplan-Meier survival analysis (Kaplan and Meier, 1958) was performed. Differences between species survivorship within an individual treatment were also examined using a survival analysis. Survival (e.g., dead or alive after completion of experiment) was examined with an original logistic model to look for interactions between species and aerial exposure. All statistics were performed separately for each of the four individual exper-

Table 1

Four-way nested mixed-effect model ANOVA of growth (both length and weight) where Season of Trial (i.e., summer 2004) is a random factor and all others are fixed

\begin{tabular}{|c|c|c|c|c|c|c|c|c|c|c|}
\hline \multirow[b]{2}{*}{ Source $^{1}$} & \multicolumn{5}{|c|}{ Change in Length } & \multicolumn{5}{|c|}{ Change in Weight } \\
\hline & $\mathrm{DF}$ & MS & $F$ & $P$ & Significance $^{2}$ & DF & MS & $F$ & $P$ & Significance $^{2}$ \\
\hline Water & 1 & 6.69 & 13.60 & 0.0002 & $*$ & 1 & 1.46 & 48.13 & $<0.0001$ & $*$ \\
\hline Trial (Water) & 2 & 2.93 & 5.96 & 0.0027 & $*$ & 2 & 2.47 & 80.93 & $<0.0001$ & $*$ \\
\hline Aerial & 3 & 31.11 & 73.72 & $<0.0001$ & $*$ & 3 & 1.00 & 12.00 & 0.0061 & $*$ \\
\hline Species & 1 & 221.77 & 46.20 & 0.021 & $*$ & 1 & 11.49 & 10.07 & 0.0866 & ns \\
\hline Water $\times$ Aerial & 3 & 1.70 & 4.03 & 0.0641 & ns & 3 & 0.040 & 0.047 & 0.9852 & ns \\
\hline Water $\times$ Species & 1 & 22.30 & 4.60 & 0.1652 & ns & 1 & 0.97 & 0.91 & 0.4418 & ns \\
\hline Trial (Water) × Aerial & 6 & 0.42 & 2.53 & 0.523 & ns & 6 & 0.082 & 2.71 & 0.0131 & $*$ \\
\hline Trial $($ Water $) \times$ Species & 2 & 4.80 & 9.74 & $<0.0001$ & $*$ & 2 & 1.07 & 35.22 & $<0.0001$ & $*$ \\
\hline Aerial $\times$ Species & 3 & 13.83 & 153.70 & $<0.0001$ & $*$ & 3 & 0.47 & 25.56 & 0.0008 & $*$ \\
\hline Water $\times$ Aerial $\times$ Species & 3 & 0.74 & 8.20 & 0.0152 & $*$ & 3 & 0.012 & 3.54 & 0.0878 & ns \\
\hline \multicolumn{11}{|l|}{ Temperature $($ Water $) \times$} \\
\hline Aerial $\times$ Species & 6 & 0.09 & 0.19 & 0.9809 & ns & 6 & 0.0031 & 0.10 & 0.9959 & ns \\
\hline Error & 10,80 & 0.49 & & & & 10,30 & 0.030 & & & \\
\hline
\end{tabular}

${ }^{1}$ Water $=$ water temperature of $12{ }^{\circ} \mathrm{C}$ or $18{ }^{\circ} \mathrm{C}$; Trial $=$ time period when the experiments were run; Aerial $=$ exposure treatment during low tide; and Species $=$ M. galloprovincialis and $M$. trossulus

${ }^{2}$ Asterisk (*) indicates that $P$ is significant at the 0.05 level; ns indicates that $P$ is nonsignifiant. 
iments (i.e., $18{ }^{\circ} \mathrm{C} 2004,18{ }^{\circ} \mathrm{C} 2005$, summer and winter 2005 at $12{ }^{\circ} \mathrm{C}$ ). Survival analyses were done with JMP 5.1.

\section{Results}

\section{Temperature monitoring}

Although lamp height was adjusted periodically, the hotand warm-treatment lamps remained, on average, at $60 \mathrm{~cm}$ and $70 \mathrm{~cm}$, respectively, above the mussels. The body temperatures of the mussels in the cool treatment remained at ambient air temperature $\left(\approx 20{ }^{\circ} \mathrm{C}\right)$. Daily body temperature highs during intertidal exposures were very close to expected values during the experiments; however, there were some variations that were partially due to fluctuations in the room conditions (Table 2). Water temperatures varied slightly more than anticipated. The mean temperature in the $18^{\circ} \mathrm{C}$ water treatment was $16.9^{\circ} \mathrm{C}$ with a standard deviation of $\pm 0.71{ }^{\circ} \mathrm{C}$ in 2004 and $18.42 \pm 0.86{ }^{\circ} \mathrm{C}$ in 2005 (Table 2). For the $12{ }^{\circ} \mathrm{C}$ water treatment, the means were $12.46 \pm$ $0.84{ }^{\circ} \mathrm{C}$ in the winter and $11.90 \pm 0.65{ }^{\circ} \mathrm{C}$ in the summer of 2005 (Table 2).

\section{Growth}

$18{ }^{\circ} \mathrm{C}$ water experiments. Aerial exposure treatments affected shell length growth differently for each species in both 2004 and 2005 (interactions between species and treatment: $P<0.0001$; Table 1) but not for weight gain (interaction: $2004, P=0.29 ; 2005, P=0.07$ ). There was a significant effect of aerial exposure for $M$. galloprovincialis on shell length growth (2004: $F_{3,86}=13.09, P<0.0001$; 2005: $\left.F_{3,175}=26.34, P<0.0001\right)$ and weight gain (2004: $\left.F_{3,87}=4.5, P=0.0055 ; 2005: F_{3,175}=15.6, P<0.0001\right)$, but no significant effects were observed with $M$. trossulus (Table 3 and Fig. 1a). Growth was significantly higher only in the immersed mussels compared to all three periodically emersed treatments for M. galloprovincialis (all comparisons, $P<0.007$; Table 3 and Fig. 1a). Therefore, no significant effect of different aerial body temperatures (e.g., $20^{\circ} \mathrm{C} v$ s. $25^{\circ} \mathrm{C}$ ) on growth was observed for either species when animals were exposed to $18{ }^{\circ} \mathrm{C}$ water. $M$. galloprovincialis grew more than $M$. trossulus when comparisons were made between all treatments for shell length and weight gain (all comparisons, $P<0.01$ ); growth was very limited in M. trossulus (Table 3 and Fig. 1a).

$12^{\circ} \mathrm{C}$ water experiments. Under $12^{\circ} \mathrm{C}$ conditions, aerial exposure treatments affected the species' shell length growth and weight gain differently in both winter and summer 2005 experiments compared to the $18{ }^{\circ} \mathrm{C}$ experiments (interactions: $P<0.0001$; Table 1). There was a significant effect of aerial body temperature on $M$. galloprovincialis shell length growth (winter: $F_{3,211}=60.8, P<$ 0.0001; summer: $F_{3,176}=24.25, P<0.0001$; Table 3 and Fig. 1b) and weight gain (winter: $F_{3,209}=32.23, P<$ 0.0001; summer: $\left.F_{3,176}=24.2, P<0.0001\right)$. Similarly, there was a significant effect of aerial body temperature on shell length growth in $M$. trossulus (winter: $F_{3,133}=3.8$, $P<0.01$; summer: $\left.F_{3,175}=26.34, P<0.0001\right)$. The effect of treatment on weight gain in M. trossulus differed between the summer and winter experiments, with a significant effect of treatment observed in the summer experiment but not in the winter (summer: $F_{3,152}=19.76, P<0.0001$ ). When pairwise comparisons were made, shell length and weight gain growth was significantly affected by the aerial exposure treatments, including the simulated subtidal mussels, for M. galloprovincialis but only between the simulated subtidal treatment and all of the aerial exposure treatments for M. trossulus (see Table 3 and Fig. 1b). However, for both species, growth decreased going from the least thermal stressful condition-simulated subtidal — to the most thermally stressful condition- hot aerial exposure treatment. M. galloprovincialis grew more than M. trossulus when comparisons were made in the winter and summer between all treatments for shell length and weight gain (all comparisons, $P \leq 0.01$ ) except the hot treatment of the winter trial.

\section{Survival}

$18{ }^{\circ} \mathrm{C}$ water experiments. There were no significant effects of aerial exposure treatment on survival for either $M$.

Table 2

Average daily high mussel body temperature experienced by mussel thermal mimics in a variety of thermal habitats throughout the laboratory experiments ( \pm std dev) in $18^{\circ} \mathrm{C}$ and $12^{\circ} \mathrm{C}$ water

\begin{tabular}{|c|c|c|c|c|c|}
\hline \multirow[b]{2}{*}{ Water temperature } & \multicolumn{2}{|c|}{ Water temperature $^{1}$} & \multicolumn{3}{|c|}{ Body temperature $^{2}$} \\
\hline & Trial & Subtidal & Cool $\left(20^{\circ} \mathrm{C}\right)$ & Warm $\left(25^{\circ} \mathrm{C}\right)$ & Hot $\left(30^{\circ} \mathrm{C}\right)$ \\
\hline \multirow[t]{2}{*}{$18^{\circ} \mathrm{C}$} & Summer 2004 & $17.53 \pm 2.13^{\circ} \mathrm{C}$ & $19.87 \pm 2.26^{\circ} \mathrm{C}$ & $26.73 \pm 2.39^{\circ} \mathrm{C}$ & $31.68 \pm 3.60{ }^{\circ} \mathrm{C}$ \\
\hline & Summer 2005 & $19.11 \pm 1.36{ }^{\circ} \mathrm{C}$ & $20.89 \pm 1.22{ }^{\circ} \mathrm{C}$ & $26.58 \pm 2.05^{\circ} \mathrm{C}$ & $30.18 \pm 2.71{ }^{\circ} \mathrm{C}$ \\
\hline \multirow[t]{2}{*}{$12{ }^{\circ} \mathrm{C}$} & Winter 2005 & $13.44 \pm 1.62{ }^{\circ} \mathrm{C}$ & $19.16 \pm 2.40^{\circ} \mathrm{C}$ & $25.74 \pm 2.07^{\circ} \mathrm{C}$ & $31.02 \pm 2.99{ }^{\circ} \mathrm{C}$ \\
\hline & Summer 2005 & $13.35 \pm 1.60^{\circ} \mathrm{C}$ & $19.20 \pm 2.17{ }^{\circ} \mathrm{C}$ & $24.05 \pm 2.93^{\circ} \mathrm{C}$ & $29.65 \pm 3.46{ }^{\circ} \mathrm{C}$ \\
\hline
\end{tabular}

\footnotetext{
${ }^{1}$ Subtidal mussels remained underwater during the entire experiment, thus the body temperature mimics the water temperature.

${ }^{2}$ Body temperatures during a simulated low tide intertidal exposure.
} 
Table 3

Growth and survival of Mytilus galloprovincialis and M. trossulus under a variety of simulated intertidal thermal conditions

\begin{tabular}{|c|c|c|c|c|c|c|}
\hline Trial & Species & $\begin{array}{l}\text { Intertidal } \\
\text { treatment }\end{array}$ & $n^{1}$ & $\begin{array}{l}\text { Change in length }^{2} \\
(\mathrm{~mm} \pm \mathrm{std} \text { err })\end{array}$ & $\begin{array}{c}\text { Change in weight }{ }^{2} \\
(\mathrm{~g} \pm \text { std err })\end{array}$ & $\begin{array}{c}\text { Percent } \\
\text { survival after } \\
9 \text { weeks }\end{array}$ \\
\hline \multicolumn{7}{|c|}{ a) Experiments run in $18{ }^{\circ} \mathrm{C}$ water } \\
\hline \multirow[t]{8}{*}{ Summer 2004} & M. galloprovincialis & Hot $\left(30^{\circ} \mathrm{C}\right)$ & $26(30)$ & $1.60 \pm 0.15 \mathrm{a}$ & $0.35 \pm 0.05 \mathrm{a}$ & 87 \\
\hline & & Warm $\left(25^{\circ} \mathrm{C}\right)$ & $17(24)$ & $1.54 \pm 0.19 \mathrm{a}$ & $0.33 \pm 0.06 \mathrm{a}$ & 79 \\
\hline & & $\operatorname{Cool}\left(20^{\circ} \mathrm{C}\right)$ & $21(27)$ & $1.30 \pm 0.17 \mathrm{a}$ & $0.33 \pm 0.05 \mathrm{a}$ & 90 \\
\hline & & Subtidal & $26(32)$ & $2.60 \pm 0.15 \mathrm{~b}$ & $0.54 \pm 0.05 \mathrm{~b}$ & 81 \\
\hline & M. trossulus & Hot $\left(30^{\circ} \mathrm{C}\right)$ & $11(29)$ & $0.18 \pm 0.09 \mathrm{a}$ & $0.15 \pm 0.03 \mathrm{a}$ & 41 \\
\hline & & Warm $\left(25^{\circ} \mathrm{C}\right)$ & $13(26)$ & $0.27 \pm 0.08 \mathrm{a}$ & $0.11 \pm 0.03 \mathrm{a}$ & 50 \\
\hline & & $\operatorname{Cool}\left(20^{\circ} \mathrm{C}\right)$ & $8(27)$ & $0.10 \pm 0.10 \mathrm{a}$ & $0.10 \pm 0.04 \mathrm{a}$ & 44 \\
\hline & & Subtidal & $11(25)$ & $0.37 \pm 0.09 \mathrm{a}$ & $0.16 \pm 0.03 \mathrm{a}$ & 37 \\
\hline \multirow[t]{8}{*}{ Summer 2005} & M. galloprovincialis & Hot $\left(30^{\circ} \mathrm{C}\right)$ & $42(51)$ & $1.39 \pm 0.14 \mathrm{a}$ & $0.43 \pm 0.04 \mathrm{a}$ & 94 \\
\hline & & Warm $\left(25^{\circ} \mathrm{C}\right)$ & $45(51)$ & $1.44 \pm 0.14 \mathrm{a}$ & $0.48 \pm 0.03 \mathrm{a}$ & 92 \\
\hline & & $\operatorname{Cool}\left(20^{\circ} \mathrm{C}\right)$ & $47(54)$ & $1.36 \pm 0.13 \mathrm{a}$ & $0.45 \pm 0.03 \mathrm{a}$ & 88 \\
\hline & & Subtidal & $45(52)$ & $2.78 \pm 0.14 \mathrm{~b}$ & $0.73 \pm 0.03 \mathrm{~b}$ & 94 \\
\hline & M. trossulus & Hot $\left(30^{\circ} \mathrm{C}\right)$ & $7(52)$ & $0.30 \pm 0.21 \mathrm{a}$ & $0.07 \pm 0.02 \mathrm{a}$ & 13 \\
\hline & & Warm $\left(25^{\circ} \mathrm{C}\right)$ & $10(48)$ & $0.45 \pm 0.18 \mathrm{a}$ & $0.11 \pm 0.02 \mathrm{a}$ & 25 \\
\hline & & $\operatorname{Cool}\left(20^{\circ} \mathrm{C}\right)$ & $8(51)$ & $0.43 \pm 0.20 \mathrm{a}$ & $0.11 \pm 0.02 \mathrm{a}$ & 32 \\
\hline & & Subtidal & $13(52)$ & $0.59 \pm 0.15 \mathrm{a}$ & $0.15 \pm 0.01 \mathrm{a}$ & 19 \\
\hline \multicolumn{7}{|c|}{ b) Experiments run in $12{ }^{\circ} \mathrm{C}$ water } \\
\hline \multirow[t]{8}{*}{ Winter 2005} & M. galloprovincialis & Hot $\left(30^{\circ} \mathrm{C}\right)$ & $32(68)$ & $0.49 \pm 0.09 \mathrm{a}$ & $0.03 \pm 0.02 \mathrm{a}$ & 50 \\
\hline & & Warm $\left(25^{\circ} \mathrm{C}\right)$ & $61(68)$ & $0.69 \pm 0.07 \mathrm{~b}$ & $0.12 \pm 0.02 \mathrm{~b}$ & 94 \\
\hline & & $\operatorname{Cool}\left(20^{\circ} \mathrm{C}\right)$ & $61(64)$ & $0.98 \pm 0.07 \mathrm{~b}$ & $0.15 \pm 0.02 \mathrm{~b}$ & 98 \\
\hline & & Subtidal & $61(63)$ & $1.76 \pm 0.07 \mathrm{c}$ & $0.29 \pm 0.02 \mathrm{c}$ & 98 \\
\hline & M. trossulus & Hot $\left(30^{\circ} \mathrm{C}\right)$ & $17(58)$ & $0.37 \pm 0.10 \mathrm{a}$ & $0.05 \pm 0.02 \mathrm{a}$ & 29 \\
\hline & & Warm $\left(25^{\circ} \mathrm{C}\right)$ & $34(63)$ & $0.44 \pm 0.07 \mathrm{a}$ & $0.06 \pm 0.01 \mathrm{a}$ & 55 \\
\hline & & $\operatorname{Cool}\left(20^{\circ} \mathrm{C}\right)$ & $36(55)$ & $0.54 \pm 0.07 \mathrm{ab}$ & $0.10 \pm 0.01 \mathrm{a}$ & 69 \\
\hline & & Subtidal & $50(65)$ & $0.69 \pm 0.06 \mathrm{~b}$ & $0.06 \pm 0.01 \mathrm{a}$ & 86 \\
\hline \multirow[t]{8}{*}{ Summer 2005} & M. galloprovincialis & Hot $\left(30^{\circ} \mathrm{C}\right)$ & $45(51)$ & $0.72 \pm 0.14 \mathrm{a}$ & $0.29 \pm 0.03 \mathrm{a}$ & 90 \\
\hline & & Warm $\left(25^{\circ} \mathrm{C}\right)$ & $49(50)$ & $0.97 \pm 0.14 \mathrm{ab}$ & $0.36 \pm 0.03 \mathrm{ab}$ & 98 \\
\hline & & $\operatorname{Cool}\left(20^{\circ} \mathrm{C}\right)$ & $41(51)$ & $1.24 \pm 0.15 \mathrm{~b}$ & $0.40 \pm 0.03 \mathrm{~b}$ & 94 \\
\hline & & Subtidal & $45(51)$ & $2.30 \pm 0.14 \mathrm{c}$ & $0.66 \pm 0.03 \mathrm{c}$ & 84 \\
\hline & M. trossulus & Hot $\left(30^{\circ} \mathrm{C}\right)$ & $40(54)$ & $0.19 \pm 0.07 \mathrm{a}$ & $0.10 \pm 0.01 \mathrm{a}$ & 76 \\
\hline & & Warm $\left(25^{\circ} \mathrm{C}\right)$ & $43(51)$ & $0.18 \pm 0.07 \mathrm{a}$ & $0.11 \pm 0.01 \mathrm{a}$ & 86 \\
\hline & & $\operatorname{Cool}\left(20^{\circ} \mathrm{C}\right)$ & $36(55)$ & $0.28 \pm 0.07 \mathrm{a}$ & $0.16 \pm 0.01 \mathrm{~b}$ & 76 \\
\hline & & Subtidal & $37(50)$ & $0.63 \pm 0.07 \mathrm{~b}$ & $0.21 \pm 0.01 \mathrm{c}$ & 71 \\
\hline
\end{tabular}

\footnotetext{
${ }^{1} n$ refers to the number alive at the end of the 9-week experiment where the length and growth measurements could be taken; the number in parentheses refers to starting sample size.

${ }^{2}$ Letters next to the length and weight growth measurements refer to the pairwise comparisons between the treatments; length and weight measurements with the same letter are not significantly different from one another.
}

galloprovincialis or M. trossulus in either the 2004 or 2005 experiments when animals were exposed to $18{ }^{\circ} \mathrm{C}$ water (Fig. 2a, b). However, there were significant differences between species survivorship within each treatment in 2004 and 2005 (all comparisons, $P<0.0001$; no interaction between species and aerial exposure treatment: summer $2004, P=0.64$; summer $2005, P=0.14$ ). Survival was relatively high for $M$. galloprovincialis; the survival rates after 9 weeks were $84 \%$ and $92 \%$ in 2004 and 2005, respectively (Table 3). Alternatively, survivorship was low for $M$. trossulus during the same period: $42 \%$ in 2004 and $22 \%$ in 2005 (Table 3).

$12{ }^{\circ} \mathrm{C}$ water experiments. Under $12{ }^{\circ} \mathrm{C}$ water conditions, in the winter 2005 trial, significant treatment differences in survival rates were observed in both $M$. galloprovincialis and $M$. trossulus $(P<0.0001$; Fig. $2 \mathrm{c})$, and there was a significant survival interaction between species and aerial exposure (interaction: $P=0.02$ ). For $M$. galloprovincialis, survival rate was reduced in the hot treatment (50\%), but it was relatively high for the other three treatments $(94 \%-$ 98\%; Table 3). M. trossulus also had a reduced survival rate in the hot treatment (29\%), but unlike M. galloprovincialis, survival slowly increased as severity of simulated intertidal exposure decreased: warm (55\%), cool (69\%), and subtidal (86\%). In all treatments the survival rates of $M$. galloprovincialis were higher than those of $M$. trossulus $(P<0.05)$. When the experiment was repeated in summer 2005 with a similar set of environmental conditions, no significant ef- 

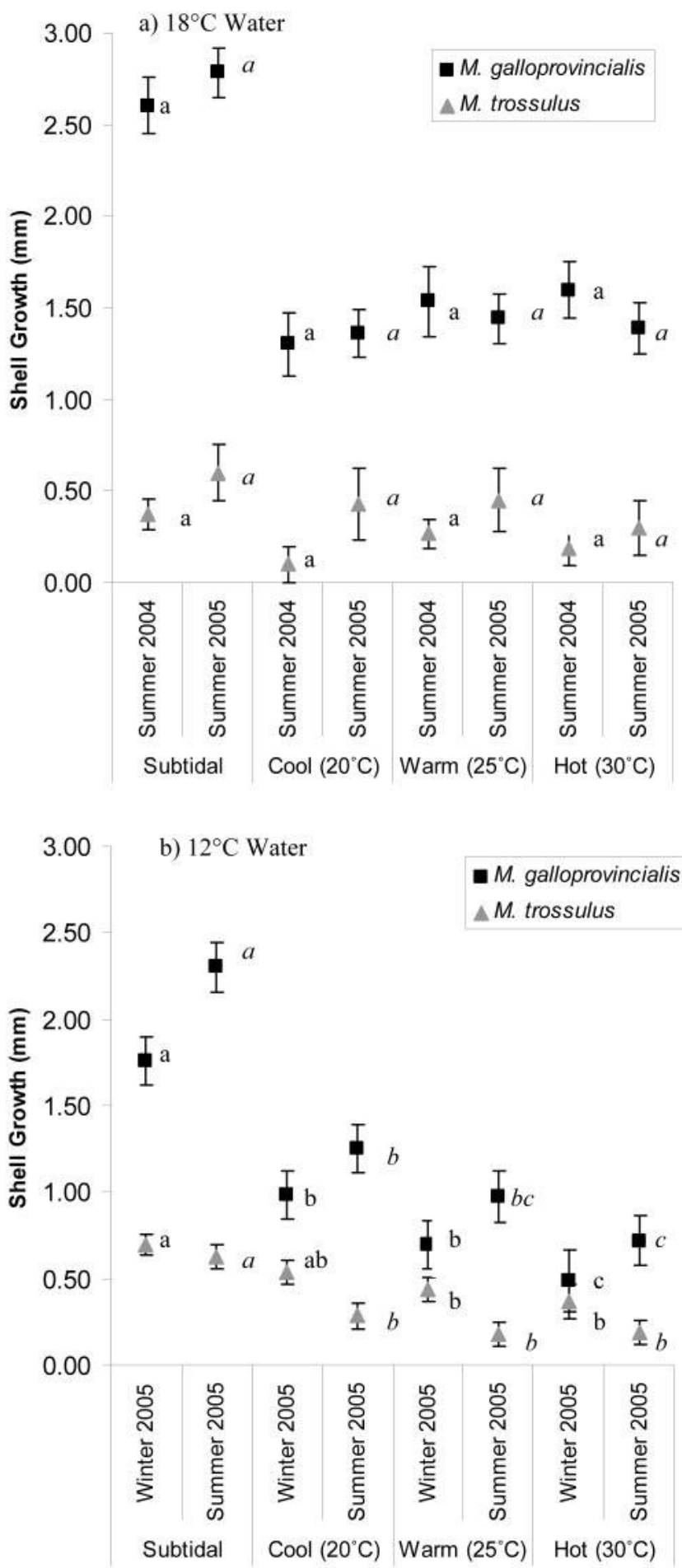

Figure 1. Growth in length of Mytilus galloprovincialis and M. trossulus under a variety of simulated intertidal thermal conditions in (a) $18{ }^{\circ} \mathrm{C}$ or (b) $12{ }^{\circ} \mathrm{C}$ water. Length measurements refer to the average change in length at the end of the 9-week experiment; bars around individual points represent the standard error. Letters refer to the pairwise comparisons between the treatments for each species; length measurements with the same letter are not significantly different from one and another (note: letters for the second run of each water temperature are italicized). fects of aerial treatment were observed for either $M$. trossulus or M. galloprovincialis; survival was relatively high in all treatments for both species (Fig. 2d), and there was not a significant survival interaction between species and aerial exposure treatment (interaction: $P=0.64$ ). Differences between M. galloprovincialis and M. trossulus were only marginally significant or were nonsignificant in summer 2005 (hot, $P=0.06$; warm, $P=0.03$; cool, $P=0.1$; subtidal, $P=0.02$ ), with $M$. galloprovincialis having slightly higher survival than M. trossulus (Fig. 2d).

\section{Discussion}

In this research I examined the role that intertidal and subtidal thermal stress plays with regard to the growth and survival of an invasive (Mytilus galloprovincialis) and native (M. trossulus) marine mussel. Previous work has investigated thermal tolerance differences between these two species with regard to water temperature (see Hofmann and Somero, 1996a; Braby and Somero, 2006a, b) but not aerial exposure (however, see Schneider and Helmuth, 2007, who examined patterns of species distribution in the field). The present study provides data that generally confirm the findings of previous work on the physiological differences in water temperature adaptation between the two species. This study also contributes the first experimental evidence concerning the role that aerial exposure during low tide plays with respect to growth and survival of the two species. Additionally, data show that M. galloprovincialis has higher growth and survival rates than $M$. trossulus, regardless of the temperature regimes examined, which supports the hypothesis presented in the introduction that M. galloprovincialis would show higher levels of growth and survival in both warmer water and aerial environments than would $M$. trossulus. However the nature of the differences between the species varied across and within the different experiments and treatments.

M. galloprovincialis demonstrated a higher survival than M. trossulus in both $18{ }^{\circ} \mathrm{C}$ and $12{ }^{\circ} \mathrm{C}$ water temperatures. In $12{ }^{\circ} \mathrm{C}$ water the differences between the species were small, whereas the differences were much larger in $18{ }^{\circ} \mathrm{C}$ water. This pattern of results suggests that $18{ }^{\circ} \mathrm{C}$ was detrimentally warm for $M$. trossulus and more suitable for M. galloprovincialis. $M$. trossulus mortality began during the first weeks of the study and continued throughout both $18{ }^{\circ} \mathrm{C}$ experiments. A $20 \%$ decrease in $M$. trossulus survival was observed in 2005 compared to 2004 , which may be due to higher water temperature in $2005\left(18.4{ }^{\circ} \mathrm{C}\right)$ compared to the $2004\left(16.9^{\circ} \mathrm{C}\right)$ experiment (see results).

Heat-shock analyses (Hofmann and Somero, 1996a; Braby and Somero, 2006a) and observational studies (Sarver and Foltz, 1993; Suchanek et al., 1997) are in accord with the present laboratory results suggesting that $M$. trossulus is more heat sensitive than M. galloprovincialis. 
a)

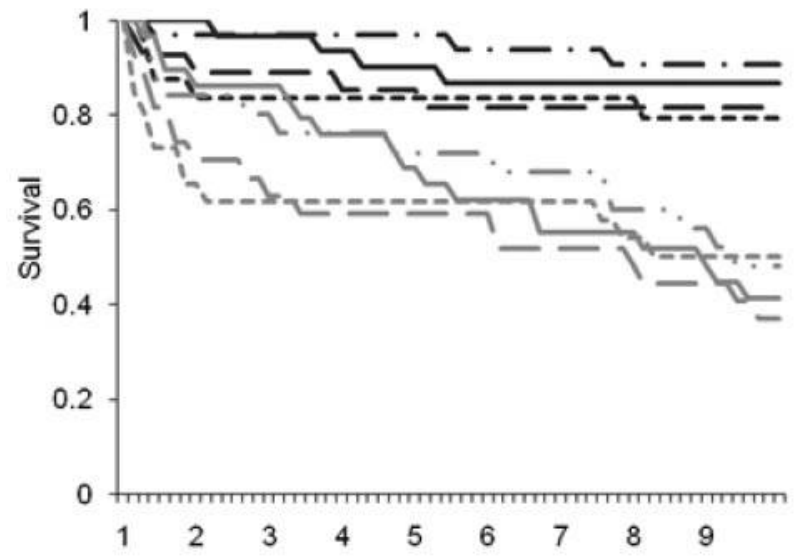

c)

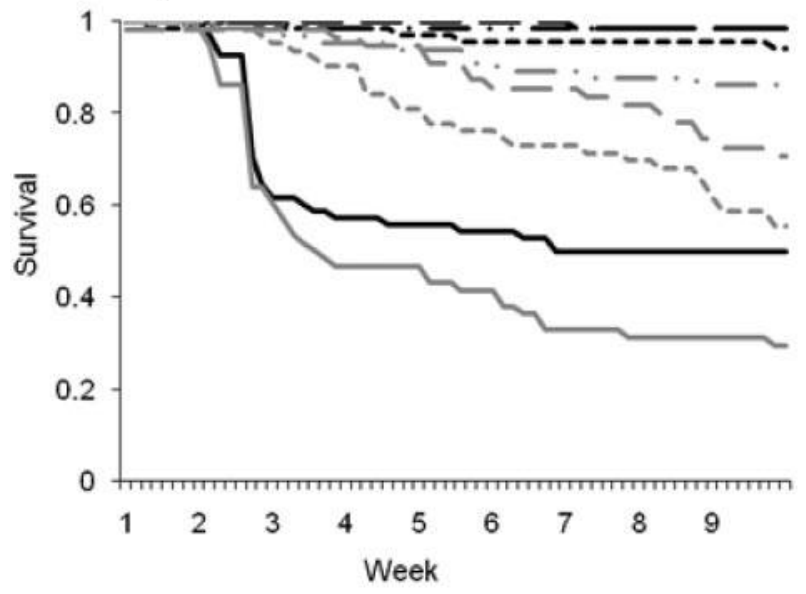

b)

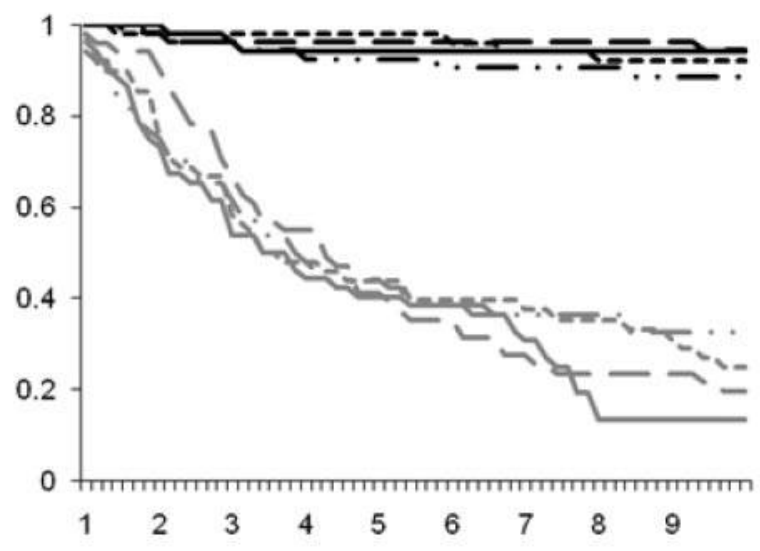

d)

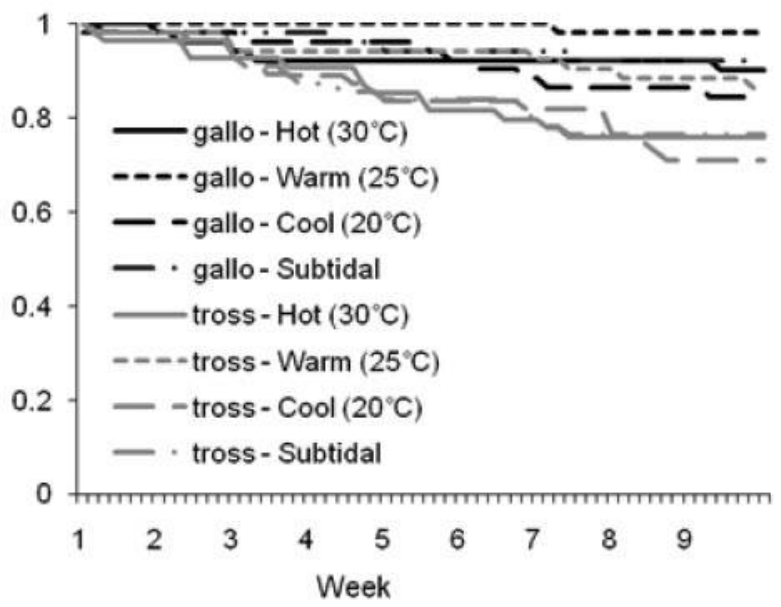

Figure 2. Survival of Mytilus galloprovincialis and M. trossulus under a variety of aerial exposure treatments throughout the 9-week experiment. Hot $\left(30^{\circ} \mathrm{C}\right)$, warm $\left(25^{\circ} \mathrm{C}\right)$, and cool $\left(20^{\circ} \mathrm{C}\right)$ treatments refer to mussel body temperature during simulated low tide (see Table 2). Subtidal mussels remained underwater during the entire experiment, thus the body temperature is the same as the water temperature. A key is located in the bottom right-hand graph; gallo refers to $M$. galloprovincialis, tross refers to $M$. trossulus. (a) $18{ }^{\circ} \mathrm{C}$ water temperature-Summer 2004, (b) $18{ }^{\circ} \mathrm{C}$ water temperature-Summer 2005 , (c) $12{ }^{\circ} \mathrm{C}$ water temperature-Winter 2005, (d) $12{ }^{\circ} \mathrm{C}$ water temperature-Summer 2005.

However, a recent field observational study in central California showed that $M$. trossulus was more abundant than $M$. galloprovincialis in areas with warm water temperatures, including several sites exceeding $25^{\circ} \mathrm{C}$ in maximum temperature (Braby and Somero, 2006b). The results of that study highlight the fact that factors other than temperature (e.g., salinity, larvae dispersal) can influence the distribution of organisms.

Notwithstanding the findings of Braby and Somero (2006b), the thermal preference with respect to water temperature of M. galloprovincialis and M. trossulus, as found in this and other research, is consistent with their current distribution patterns along the west coast of the United States: M. trossulus is predominantly found in cooler water from central California through Alaska, and M. gallopro- vincialis is largely found from southern California through northern California (Sarver and Foltz, 1993; Suchanek et $a l ., 1997)$. If temperatures continue to increase as a result of influences such as global warming, the thermal optimal of M. trossulus (i.e., cooler conditions) may occur less frequently, thus opening habitat for invasive warmth-tolerant species such as M. galloprovincialis.

In addition to water temperature, aerial exposure during low tide likely influences the distribution patterns of intertidal organisms. This study suggests that the role played by low tide heat stress is probably complicated by multiple factors but remains an important variable in understanding intertidal ecology. Intertidal exposure can have negative effects on the growth and survival of organisms.

In both $12{ }^{\circ} \mathrm{C}$ experiments (i.e., winter and summer), 
growth was affected by aerial exposure, although this trend was much stronger with $M$. galloprovincialis than with $M$. trossulus, likely due to the profound growth differences between the two species (i.e., M. galloprovincialis grew more). The higher intertidal temperatures were associated with lower growth, particularly in M. galloprovincialis. In the $12{ }^{\circ} \mathrm{C}$ water there was also a negative effect of aerial exposure on the survival of both species, although the effect was greater for M. trossulus. This negative effect on survival was observed only in the winter trial. There are several possible reasons for this finding. Differences could be due to a seasonal effect on intertidal mortality such as shifts in water temperature (i.e., thermal acclimation) and food availability. Warmer water temperatures in Puget Sound $(\approx 8-10$ ${ }^{\circ} \mathrm{C}$ in January, $11-12{ }^{\circ} \mathrm{C}$ in June, see Methods), where the mussels were raised, may have reduced the effect of low tide exposure in the laboratory in the summer trial (e.g., Tomanek and Somero, 1999; Stillman and Somero, 2000; Buckley et al., 2001). Food availability also often follows seasonal cycles. In Puget Sound, phytoplankton abundance is very limited in the winter compared to spring and early summer (Newton and Van Voorhis, 2002). The limited food supply during the winter may have had a lasting effect on the mussels' ability to handle thermal stress (see Braid et $a l ., 2005)$. The prior opportunity to feed in the summer trials may have left the mussels with more energy to combat thermal stress, thus no lethal effects of aerial exposure were seen, although sublethal effects (i.e., growth) were still apparent. This hypothesis requires further investigation. If it is correct, low tide thermal stress events may have a greater effect on survival when they occur after periods of low food availability than they would when food was abundant.

Contrary to the $12{ }^{\circ} \mathrm{C}$ experiments, there was not a significant effect of intertidal exposure temperatures on growth or survival in the $18{ }^{\circ} \mathrm{C}$ water experiments. However, these trials occurred only during the summer, and as was observed with the $12{ }^{\circ} \mathrm{C}$ water experiments, there may have been a seasonal effect in ability to handle low tide stress with regard to survival. Still, in $18{ }^{\circ} \mathrm{C}$, neither species showed the kind of influence on growth that was observed in $12{ }^{\circ} \mathrm{C}$ water. Thermal acclimation to aerial exposure due to warmer water conditions has been documented in other species (see Tomanek and Somero, 1999; Stillman and Somero, 2000), as well as in M. trossulus (Buckley et al., 2001). Thus, the mussels held in $18{ }^{\circ} \mathrm{C}$ water were acclimated to the warmer conditions and likely had less difficulty adjusting to higher body temperatures during low tide.

Although water temperatures tend to follow a latitudinal cline, the body temperatures of intertidal species when measured at low tide do not always follow a similar pattern. Thermal stress during low tide is determined by a complex interaction involving factors such as timing of low tide, terrestrial climate, and wave splash, all of which fluctuate along a coastline (Helmuth et al., 2002, 2006; Gilman et al.,
2006). Thus, some northern sites with cool water temperatures may experience warmer low tide body temperatures than southern intertidal sites. Along the west coast of North America, intertidal low tide "hot spots" occur within the range of M. trossulus (Helmuth et al., 2002). If M. trossulus is more sensitive to warm low tide aerial exposure, than one may expect the abundance or fitness of $M$. trossulus to be reduced in the hot spots because of thermal stress. Additionally, if the distribution of M. galloprovincialis expands north, then this species may perform better than M. trossulus in these hot spots.

Schneider and Helmuth (2007) have explored aerial exposure thermal tolerance in central California (i.e., intertidal thermal stress). $M$. trossulus genotypes were found in higher frequency in (1) shaded compared to exposed intertidal sites and (2) subtidal compared to intertidal sites (Schneider and Helmuth, 2007). These frequency differences between habitats may be a signature of selection against $M$. trossulus in aerial exposed thermal environments. The laboratory results reported in the present study showed that $M$. trossulus did have increased mortality compared to M. galloprovincialis when exposed to warmer thermal environments, but only in the winter $12{ }^{\circ} \mathrm{C}$ water experiment.

M. galloprovincialis had a higher growth rate than $M$. trossulus in each of the experiments. In natural populations, M. galloprovincialis appears to have a larger maximal size than M. trossulus (Braby and Somero, 2006b; Schneider, unpubl. data). If $M$. trossulus is genetically smaller, this may explain its reduced growth rate in the present research; older mussels grow less (e.g., Sukhotin et al., 2002). The size of the two species (i.e., $20-30 \mathrm{~mm}$ in length) was controlled in the experiment but age was not. Mussels in the $M$. edulis complex that are $20-30 \mathrm{~mm}$ in length can be between from less than 1 year to 7 years in age depending on the habitat and environmental conditions in which they were raised (reviewed in Seed, 1976). Additionally, mussels within the M. edulis complex can mature within the first year of life (Seed and Suchanek, 1992). However, no direct reproductive comparisons have been made between M. trossulus and M. galloprovincialis (for more information about Mytilus spp. reproductive timing, see Gosling, 2003; CurielRamirez and Caceres-Martinez, 2004). If one of the species in the laboratory experiments was directing more resources toward reproductive efforts at the time of the study (see Secor et al., 2001), this could have affected the results. The above considerations suggest the importance of controlling for age and reproductive maturity as well as for body size in future comparative investigations of growth and survival.

Other factors can also account for growth and survival differences between $M$. trossulus and M. galloprovincialis. For example, neoplasia ("mussel leukemia") is common in populations of $M$. trossulus, but is rarely seen in those of $M$. galloprovincialis (Moore et al., 1991; Elston et al., 1992; Ciocan and Sunila, 2005). The lethality of neoplasia may 
increase at higher temperatures: elevated mortality with temperature increases has been observed with other bivalve diseases (reviewed in Gosling, 2003). If any of the study organisms were infected with this disease, it could explain the differences in survival observed in this study. In addition, $M$. trossulus may be more sensitive than $M$. galloprovincialis to captivity (e.g., Braby and Somero, 2006a). Lastly, many other aspects of bivalve physiology are affected during low tide aerial exposure, such as immunity, reproductive stress, and acid-base balance. Clearly, rigorous field studies and expanded laboratory studies are necessary to determine how aerial exposure and water temperature (and the interaction of the two factors) affect intertidal distribution patterns.

Global temperatures are predicted to rise (Solomon et al., 2007). Empirical and theoretical works suggest that the frequency of non-native invasions will increase, and the range of existing invaders will spread (Beerling et al., 1995; Kremer et al., 1996; Dukes and Mooney, 1999; Stachowicz et al., 2002; Kriticos et al., 2003). The differences found between $M$. galloprovincialis and M. trossulus in thermal physiology support the thesis that climate change facilitates species invasions. M. galloprovincialis outperforms its sibling species, $M$. trossulus, in warm thermal conditions, and the current results suggest that M. galloprovincialis will spread, at least vis-à-vis M. trossulus, as water and air temperatures increase. On the other hand, M. galloprovincialis's sibling species, $M$. trossulus, is likely to remain a non-invader, and current southern distributions may retract due to low survivorship in warmer conditions. Considering the large negative effects that invasive species frequently have on ecosystems (e.g., Pimentel et al., 2000), understanding how invasive species interact with their thermal environments increases our insight into their current and future distributions. Future studies should continue to explore how subtidal and intertidal temperatures influence the adaptation of invasive and native species to both laboratory and field environments. Field studies that complement the laboratory experiments presented here will increase our understanding of the interaction between abiotic stressors and the success of invasive species in intertidal communities. Work that examines intertidal thermal stresses will facilitate our knowledge of current distribution patterns while helping to predict future distributions under a variety of climate scenarios.

\section{Acknowledgments}

I thank B. Helmuth for his help and support throughout the experimental design process and implementation. I also thank J. Adams for his assistance in creating and maintaining the aquaria used in this study. I. Jefferds and his colleagues at Penn Cove Shellfish provided the mussels and insights into their mussel populations. Special thanks go to
C. Van Koughnett, N. Ragaban, L. Watson, and C. Welch for help with the experiments. Early forms of this manuscript were improved by comments from B. Helmuth, K. Fedorka, S. Pincebourde, R. Raguso, F. Schneider, W. Winterhalter, and two anonymous reviewers. This work was funded by a Slocum-Lunz grant to K. Schneider and by NSF OCE-0323364 and NASA NNG04GE43G to B. Helmuth. The experiments comply with the current laws of the country in which they were performed.

\section{Literature Cited}

Agius, B. P. 2007. Spatial and temporal effect of pre-seeding plates with invasive ascidians: growth, recruitment and community composition. $J$. Exp. Mar. Biol. Ecol. 342: 30-39.

Allen, S. M., and L. E. Burnett. 2008. The effects of intertidal air exposure on the respiratory physiology and the killing activity of hemocytes in the pacific oyster, Crassostrea gigas (Thunberg). J. Exp. Mar. Biol. Ecol. 357:165-171.

Barry, J. P., C. H. Baxter, R. D. Sagarin, and S. E. Gilman. 1995. Climate-related, long-term faunal changes in a California rocky intertidal community. Science 267: 672-675.

Beerling, D. J., B. Huntley, and J. P. Bailey. 1995. Climate and the distribution of Fallopia japonica - use of an introduced species to test the predictive capacity of response surfaces. J. Veg. Sci. 6: 269-282.

Blackburn, T. M., and R. P. Duncan. 2001. Determinants of establishment success in introduced birds. Nature 414: 195-197.

Braby, C. E., and G. N. Somero. 2006a. Following the heart: temperature and salinity effects on heart rate in native and invasive species of blue mussels (genus Mytilus). J. Exp. Biol. 209: 2554-2566.

Braby, C. E., and G. N. Somero. 2006b. Ecological gradients and relative abundance of native (Mytilus trossulus) and invasive (Mytilus galloprovincialis) blue mussels in the California hybrid zone. Mar. Biol. 148: 1249-1262.

Braid, B. A., J. D. Moore, T. T. Robbins, R. P. Hedrick, R. S. Tjeerdema, and C. S. Friedman. 2005. Health and survival of red abalone, Haliotis rufescens, under varying temperature, food supply, and exposure to the agent of withering syndrome. J. Invertebr. Pathol. 89: 219-231.

Buckley, B. A., M.-E. Owen, and G. E. Hoffman. 2001. Adjusting the thermostat: the threshold induction temperature for the heat-shock response in intertidal mussels (genus Mytilus) changes as a function of thermal history. J. Exp. Biol. 204: 3571-3579.

Calvo-Ugarteburu, G., and C. D. McQuaid. 1998. Parasitism and invasive species: effects of digenetic trematodes on mussels. Mar. Ecol. Prog. Ser. 160: 149-163.

Carlton, J. T., and J. B. Geller. 1993. Ecological roulette-the global transport of nonindigenous marine organisms. Science 261: 78-82.

Ciocan, C., and I. Sunila. 2005. Disseminate neoplasia in blue mussels, Mytilus galloprovincialis, from the black sea, Romania. Mar. Pollut. Bull. 50: 1335-1339.

Cohen, A. N., and J. T. Carlton. 1998. Accelerating invasion rate in a highly invaded estuary. Science 279: 555-558.

Curiel-Ramirez, S., and J. Caceres-Martinez. 2004. Reproductive cycle of coexisting mussels, Mytilus californianus and Mytilus galloprovincialis, in Baja California, New Mexico. J. Shellfish Res. 23: 515520.

Dukes, J.S., and H. A. Mooney. 1999. Does global change increase the success of biological invaders? Trends Ecol. Evol. 14: 135-139.

Elston, R. A., J. D. Moore, and K. Brooks. 1992. Disseminated neoplasia of bivalve mollusks. Rev. Aquat. Sci. 6: 405-466.

Fitzhenry, T., P. M. Halpin, and B. Helmuth. 2004. Testing the effects of wave exposure, site, and behavior on intertidal mussel body tem- 
peratures: applications and limits of temperature logger design. Mar. Biol. 145: 339-349.

Geller, J. B. 1999. Decline of a native mussel masked by sibling species invasion. Conserv. Biol. 13: 661-664.

Gilman, S. E., C. D. G. Harley, D. C. Strickland, O. Vanderstraeten, M. J. O'Donnell, and B. Helmuth. 2006. Evaluation of effective shore level as a method of characterizing intertidal wave exposure regimes. Limnol. Oceanogr. Methods 4: 448-457.

Gosling, E. 2003. Bivalve Molluscs. Fishing News Books, Blackwell Publishing, Oxford, United Kingdom.

Helmuth, B. 2002. How do we measure the environment? Linking intertidal thermal physiology and ecology through biophysics. Integr. Comp. Biol. 42: 837-845.

Helmuth, B., C. D. G. Harley, P. M. Halpin, M. O'Donnell, G. E. Hofmann, and C. A. Blanchette. 2002. Climate change and latitudinal patterns of intertidal thermal stress. Science 298: 1015-1017.

Helmuth, B., B. R. Broitman, C. A. Blanchette, S. Gilman, P. Halpin, C. D. G. Harley, M. J. O'Donnell, G. E. Hofmann, B. Menge, and D. Strickland. 2006. Mosaic patterns of thermal stress in the rocky intertidal zone: implications for climate change. Ecol. Monogr. 76: 461-479.

Helmuth, B. S. T. 1998. Intertidal mussel microclimates: predicting the body temperature of a sessile invertebrate. Ecol. Monogr. 68: 51-74.

Hockey, P. A. R., and C. V. Schurink. 1992. The invasive biology of the mussel Mytilus galloprovincialis on the Southern African Coast. Trans. R. Soc. S. Afr. 48: 123-139.

Hoffman, B. D., A. N. Andersen, and G. J. E. Hell. 1999. Impact of an introduced ant on native rain forest invertebrates: Pheidole megacephala in monsoonal Australia. Oecologia 120: 595-604.

Hofmann, G. E., and G. N. Somero. 1996a. Interspecific variation in thermal denaturation of proteins in the congeneric mussels Mytilus trossulus and M. galloprovincialis: evidence from the heat shock response and protein ubiquitination. Mar. Biol. 126: 65-75.

Hofmann, G. E., and G. N. Somero. 1996b. Protein ubiquitination and stress protein synthesis in Mytilus trossulus occurs during recovery from tidal emersion. Mol. Mar. Biol. Biotech. 5: 175-184.

Kaplan, E. L., and P. Meier. 1958. Nonparametric estimation from incomplete observations. J. Am. Stat. Assoc. 53: 457-481.

Kremer, R. G., E. R. Hunt, S. W. Running, and J. C. Coughlan. 1996. Simulating vegetational and hydrologic responses to natural climatic variation and GCM-predicted climate change in a semi-arid ecosystem in Washington, USA. J. Arid Environ. 33: 23-38.

Kriticos, D. J., R. W. Sutherst, J. R. Brown, S. W. Adkins, and G. F. Maywald. 2003. Climate change and the potential distribution of an invasive alien plant: Acacia nilotica ssp. indica in Australia. J. Appl. Ecol. 40: 111-124.

Lee, S. Y., and B. S. Morton. 1985. The introduction of the Mediterranean mussel Mytilus galloprovincialis into Hong Kong. Malacol. Rev. 18: 107-109.

Lowe, S., M. Browne, S. Boudjelas, and M. De Poorter. 2000. 100 of the World's Worst Invasive Alien Species: A Selection From the Global Invasive Species Database. Invasive Species Specialist Group of the Species Survival Commission (SSC) of the World Conservation Union (IUCN), Auckland, New Zealand. 12 pp.

Mack, R. N., D. Simberloff, W. M. Lonsdale, H. Evans, M. Clout, and F. A. Bazzaz. 2000. Biotic invasions: causes, epidemiology, global consequences, and control. Ecol. Appl. 10: 689-710.

Miller, A. W., G. M. Ruiz, M. S. Minton, and R. F. Ambrose. 2007. Differentiating successful and failed molluscan invaders in estuarine ecosystems. Mar. Ecol. Prog. Ser. 332: 41-51.

Moore, J. D., R. A. Elston, A. S. Drum, and M. T. Wilkinson. 1991. Alternate pathogenesis of systemic neoplasia in the bivalve mollusk Mytilus. J. Invertebr. Pathol. 58: 231-243.

Nehls, G., S. Diederich, D. W. Thieltges, and M. Strasser. 2006. Wad- den Sea mussel beds invaded by oysters and slipper limpets: competition or climate control? Helgol. Mar. Res. 60: 135-143.

Newton, J., and K. Van Voorhis. 2002. Seasonal Patterns and Controlling Factors of Primary Production in Puget Sound's Central Basin and Possession Sound. Washington State Department of Ecology, Environmental Assessment Program, Publication \#02-03-059, Olympia, WA.

Petes, L. E., B. A. Menge, and G. D. Murphy. 2007. Environmental stress decreases survival, growth, and reproduction in New Zealand mussels. J. Exp. Mar. Biol. Ecol. 351: 83-91.

Pimentel, D., L. Lach, R. Zuniga, and D. Morrison. 2000. Environmental and economic costs of nonindigenous species in the United States. Bioscience 50: 53-65.

Place, S. D., M. J. O'Donnell, and G. E. Hofmann. 2008. Gene expression in the intertidal mussel Mytilus californianus: physiological response to environmental factors on a biogeographic scale. Mar. Ecol. Prog. Ser. 356: 1-14.

Przeslawski, R. 2005. Combined effects of solar radiation and desiccation on the mortality and development of encapsulated embryos of rocky shore gastropods. Mar. Ecol. Prog. Ser. 298: 169-177.

Radford, I. J., and R. D. Cousens. 2000. Invasiveness and comparative life-history traits of exotic and indigenous Senecio species in Australia. Oecologia 125: 531-542.

Rawson, P. D., K. L. Joyner, K. Meetze, and T. J. Hilbish. 1996. Evidence for intragenic recombination within a novel genetic marker that distinguishes mussels in the Mytilus edulis species complex. $\mathrm{He}$ redity 77: 599-607.

Rawson, P. D., V. Agrawal, and T. J. Hilbish. 1999. Hybridization between the blue mussels Mytilus galloprovincialis and M. trossulus along the Pacific coast of North America: evidence for limited introgression. Mar. Biol. 134: 201-211.

Rejmanek, M. 1996. A theory of seed plant invasiveness: the first sketch. Biol. Conserv. 78: 171-181.

Rice, W. R. 1989. Analyzing tables of statistical tests. Evolution 43: 223-225.

Sagarin, R. D., and G. N. Somero. 2006. Complex patterns of expression of heat-shock protein 70 across the southern biogeographical ranges of the intertidal mussel Mytilus californianus and snail Nucella ostrina. J. Biogeogr. 33: 622-630.

Sagarin, R. D., J. P. Barry, S. E. Gilman, and C. H. Baxter. 1999. Climate-related change in an intertidal community over short and long time scales. Ecol. Monogr. 69: 465-490.

Sarver, S. K., and D. W. Foltz. 1993. Genetic population structure of a species complex of blue mussels (Mytilus spp). Mar. Biol. 117: 105112.

Saunders, M., and A. Metaxas. 2007. Temperature explains settlement patterns of the introduced bryozoan Membranipora membranacea in Nova Scotia, Canada. Mar. Ecol. Prog. Ser. 344: 95-106.

Sax, D. F., J. J. Stachowicz, and S. D. Gaines. 2005. Species Invasions. Insights into Ecology, Evolution, and Biogeography. Sinauer Associates, Sunderland, MA

Schneider, K. R., and B. Helmuth. 2007. Spatial variability in habitat temperature may drive patterns of selection between an invasive and native mussel species. Mar. Ecol. Prog. Ser. 339:157-167.

Schneider, K. R., D. S. Wethey, B. S. T. Helmuth, and T. J. Hilbish. 2005. Implications of movement behavior on mussel dislodgement: exogenous selection in a Mytilus spp. hybrid zone. Mar. Biol. 146: 333-343.

Secor, C. L., A. J. Day, and T. J. Hilbish. 2001. Factors influencing differential mortality within a marine mussel (Mytilus spp.) hybrid population in southwestern England: reproductive effort and parasitism. Mar. Biol. 138: 731-739.

Seed, R. 1976. Ecology. Pp. 13-66 in Marine Mussels: Their Ecology 
and Physiology, B. L. Bayne, ed. Cambridge University Press, Cambridge.

Seed, R. 1992. Systematics evolution and distribution of mussels belonging to the genus Mytilus - an overview. Am. Malacol. Bull. 9: 123-137.

Seed, R., and T. H. Suchanek. 1992. Population and community ecology of Mytilus. Pp. 87-169 in The Mussel Mytilus: Ecology, Physiology, Genetics and Culture, E. M. Gosling, ed. Elsevier, Amsterdam.

Solomon, S., D. Qin, M. Manning, M. Marquis, K. Averyt, M. M. B. Tignor. and H. L. Miller, Jr. 2007. Climate Change 2007: The Physical Science Basis, Working Group I Contribution to the Fourth Assessment Report of the Intergovernmental Panel on Climate Change, Cambridge University Press, Cambridge.

Stachowicz, J. J., J. R. Terwin, R. B. Whitlatch, and R. W. Osman. 2002. Linking climate change and biological invasions: ocean warming facilitates nonindigenous species invasions. Proc. Natl. Acad. Sci. USA 99: $15497-15500$.

Stillman, J. H., and G. N. Somero. 2000. A comparative analysis of the upper thermal tolerance limits of eastern Pacific porcelain crabs, genus Petrolisthes: influences of latitude, vertical zonation, acclimation, and phylogeny. Phvsiol. Biochem. Zool. 73: 200-208.

Suchanek, T. H., J. B. Geller, B. R. Kreiser, and J. B. Mitton. 1997. Zoogeographic distributions of the sibling species Mytilus galloprovin- cialis and M. trossulus (Bivalvia: Mytilidae) and their hybrids in the North Pacific. Biol. Bull. 193: 187-194.

Sukhotin, A. A., D. Abele, and H. O. Pörtner. 2002. Growth, metabolism and lipid peroxidation in Mytilus edulis: age and size effects. Mar. Ecol. Prog. Ser. 226: 223-234.

Tomanek, L., and G. N. Somero. 1999. Evolutionary and acclimationinduced variation in the heat-shock responses of congeneric marine snails (genus Tegula) from different thermal habitats: implications for limits of thermotolerance and biogeography. J. Exp. Biol. 202: 29252936.

Wilcove, D. S., D. Rothstein, J. Dubow, A. Phillips, and E. Losos. 1998. Quantifying threats to imperiled species in the United States. Bioscience 48: 607-615.

Wilkens, N. P., K. Fujino, and E. M. Gosling. 1983. The Mediterranean mussel Mytilus galloprovincialis Lmk. in Japan. Biol. J. Linn. Soc. 20: 365-374.

Wonham, M. J. 2004. Mini-review: distribution of the Mediterranean mussel Mytilus galloprovincialis (Bivalvia: Mytilidae) and hybrids in the Northeast Pacific. J. Shellfish Res. 23: 535-543.

Wonham, M. J., W. C. Walton, G. M. Ruiz, A. M. Frese, and B. S. Galil. 2001. Going to the source: role of the invasion pathway in determining potential invaders. Mar. Ecol. Prog. Ser. 215: 1-12. 